International Journal of English Literature and Social Sciences
Vol-6, Issue-3; May-Jun, 2021

\title{
Utilization of the New Englishes in the K-12 Curriculum English for Specific Purposes: Senior High School's Perspective
}

\author{
Emardy T. Barbecho
}

Cebu Technological University, Carmen Campus, Carmen, Philippines

Received: 30 Mar 2021; Received in revised form: 07 May 2021; Accepted: 18 May 2021; Available online: 13 Jun 2021 (C)2021 The Author(s). Published by Infogain Publication. This is an open access article under the CC BY license (https://creativecommons.org/licenses/by/4.0/).

\begin{abstract}
This study aimed to reveal the perceptions of the senior high school students in the utilization of loanwords (New Englishes) in the new k-12 English Language Curriculum English for Specific Purposes. The respondents were 46 Senior High School Students. The data were collected through interviews and analyzed through content analysis. It was found out that English for Academic Purposes was implemented properly but the challenge was the students and teachers were having a difficult strategy in familiarizing loanwords due to the lack of necessary materials, students do not have time for thorough reading, researching on the website and level of determination in Examinations.
\end{abstract}

Keywords - utilization of loanwords, perceptions on loanwords, English for Academic Purposes, content analysis, and senior high school.

\section{INTRODUCTION}

Satisfaction is characterized by the quality of products and services that the organization delivers to its customers that serves as the basis for continuous improvement (Jeremiah 2015 as cited in Buted et al.2014). To establish as a baseline standard of performance and a possible standard of excellence, the new English Curriculum in Senior High School should put and give an avenue to ignite the students' interest in learning English language. Constructivist learning theory argues that learners construct the knowledge by creating their own meaning and making connections to the previous knowledge rather than receiving it from teachers (Brooks and Brooks, 1999).

Hence, students of the new English curriculum shall see the beauty of in the utilization of English loanword usage on their written output. In the light of word barrowing, students encountered unambiguous codeswitches in showing similar linguistic characteristics during the writing session and other writing activities. In terms of word barrowing, environment has the great factors in using loan words in the students' output.

Innovative usage of vocabulary by the speakers of language, the success or failure of these innovations in achieving currency and acceptance in the speech community, and the socially conditioned variation and change in their use are the general processes of lexical dynamics which have counter parts in the barrowing and assimilation of words from other languages.

\section{Objectives of the Study}

This research work assessed the perceptions of Senior High School Studentsin the Utilization of loanwords (New Englishes) in the k-12 new English Language Curriculum, English for Academic Purposes.

Specifically, it sought to answer the following:

1. determine the linguistic features

2. Syntactic Structures

3. Semantic Features, and

4. Lexicon. 


\section{Research Questions}

1. What are the perceptions of the teachers and students about the New Englishes and Loan Words in paragraph development?

2. What are the challenges and or problems concerning the new Englishes and Loan words in Language curriculum from the perspective of the teachers and students?

\section{RESEARCH METHODOLOGY}

\section{Research Design}

In this section of the study, a qualitative method was used to conduct the research by utilizing the content analysis in terms of subjects, data gathering, tool, method of analysis.

Tool

The tool for data analysis is content analysis. This method fell within the descriptive research method.

\section{Research Participants/ Subject of the Study}

The participants of this study were the 46 Senior High School Students who took English for Academic Purposes at Carmen National High School and Five English teachers were randomly selected to examine the written output of the students.

\section{Data Gathering Procedures}

The data were collected through conducting indepth interviews with the teachers and focus group interviews with the students by utilizing semi-structured interview schedules. The respondents were instructed to write a composition entitled The Greatest Responsibility of the Students of about 150-200 words and the utilization of new Englishes in their paragraph. This title was taken from the content of the 17 Goals of Education for Sustainable Development by 2030 (ESD). Each student's work was read and examined, checked by five English Teachers. This is to attain objectivity.

\section{DATA ANALYSIS}

The composition entries were analyzed using content analysis and categorized according to the learner's perceptions in the inclusion of new Englishes and loanword in paragraph writing.

\section{Findings and Discussion}

This section discusses the findings of this study namely: the respondents' view pertaining challenges experienced in learning the proper utilization of the vocabulary, respondents' general views, comments, and observations on classroom teaching and learning experience of language features, and respondents' suggestions for teachers to enhance the transfer of learning processes and to other learners improve the communicative competence based on respondents' personal approaches.

\section{Students' Vocabulary Learning Impediments}

This provides the findings on the respondents' views pertaining to vocabulary learning impediments that have been experienced in the Language Classroom.

Table 1. Vocabulary Development problems vis-à-vis sentence construction (Linguistic Features)

\begin{tabular}{|l|l|l|}
\hline Total Participants & Challenges and Issues & Reasons \\
\hline 20 Students & $\begin{array}{l}\text { No enough knowledge in } \\
\text { using correct vocabulary in } \\
\text { sentence construction during } \\
\text { paragraph writing sessions }\end{array}$ & Worried in grammatical mistakes \\
\hline 13 students & $\begin{array}{l}\text { Their emotions were } \\
\text { disturbed during speaking } \\
\text { engagement }\end{array}$ & $\begin{array}{l}\text { Negative preliminary presumptions } \\
\text { about proficient speakers views } \\
\text { towards them such as not intelligent, } \\
\text { incompetent, and dull. (Social } \\
\text { Stigma) }\end{array}$ \\
\hline 7 students & $\begin{array}{l}\text { Unfamiliar with certain English } \\
\text { vocabulary }\end{array}$ \\
\hline 6 students & Now in generating ideas \\
\hline
\end{tabular}

In Table 1, 20 students stated that they do not have enough knowledge in using correct vocabulary in sentence construction during paragraph writing sessions. Thus, in the light of loanwords and new Englishes, it is very difficult to them to construct a paragraph with the variety of vocabulary. This is very empirical that the students were afraid of committing mistakes during the production of written output. Meanwhile, 13 students stated that their emotions were disturbed during speaking engagement due to the negative preliminary presumptions about proficient speakers' views towards them such as not intelligent, incompetent, and dull. (Social Stigma). As a 
result, the students were not fully engaged in the classroom activities even though they were constantly encouraged to participate the language activities such as writing, speaking, and other interactive activities. Indeed, these negative experiences and fear of negative judgement from others blocked the effective language learning and development among the senior high school students.

New Englishes and Loanword ProblemsImpediments Encountered by Students

Table 2. New Englishes and Loanword Problems, Reasons and Effects among Senior High School

\begin{tabular}{|l|l|l|l|}
\hline Total Participants & Challenges and Issues & Reasons & Impact and Effects \\
\hline \multirow{3}{*}{$\mathbf{3 0}$ students } & $\begin{array}{l}\text { unable to fully familiarize } \\
\text { the utilization of loan } \\
\text { words in the paragraph }\end{array}$ & $\begin{array}{l}\text { The teachers were not yet updated } \\
\text { the context and idea of loan words } \\
\text { and new Englishes. } \\
\text { The meaning of words is vague } \\
\text { for the students }\end{array}$ & $\begin{array}{l}\text { The students cannot give the idea } \\
\text { directly to the thematic content of } \\
\text { the paragraph. } \\
\text { Inaccurate response } \\
\text { semantic trouble is present. }\end{array}$ \\
\hline
\end{tabular}

\begin{tabular}{|l|l|l|l|}
\hline 11 Students & $\begin{array}{l}\text { did not see the inclusion of } \\
\text { loanwords fomiliarization of new }\end{array}$ & $\begin{array}{l}\text { No development of } \\
\text { composition and unable to } \\
\text { vocabulary and other aspects } \\
\text { of Language }\end{array}$ \\
$\begin{array}{ll}\text { generate ideas on how to } \\
\text { express the meaning and } \\
\text { content of the paragraph. }\end{array}$ & $\begin{array}{l}\text { Teachers confused the entire } \\
\text { content of new Englishes and } \\
\text { loan words. }\end{array}$ & \\
\hline 5 students & Almost no problem & & \\
\hline
\end{tabular}

In Table 2, 30 students were unable to fully familiarize the utilization of loan words in the paragraph due to that teachers were not yet updated the context and idea of loan words and new Englishes and the meaning of words is vague to the students. As a result, the students may wonder if loanwords are really significant in the writing process. Indeed, students cannot give the idea directly to the thematic content of the paragraph hence the teacher may not give the adequate explanation in utilizing the loanword. Meanwhile, 11 students did not see the inclusion of loanwords in the composition and unable to generate ideas on how to express the meaning and content of the paragraph, that is why students cannot familiarize the new Englishes and loan words and the teachers also confused the entire content of new Englishes and loan words. Thus, there were five students stated that they do not have problems in new Englishes and loan words.

\section{CONCLUSION}

The perceptions of senior high school towards new Enlgishes and loanwords were the signal on how the students reviewed seriously the mechanics in writing during the performance in the language classroom. To teach is very accommodating but to transfer the skills and knowledge are the two tough challenges that the teachers are facing. Moreover, the teachers of senior high school must have a serious and religious seminar-workshop on the current trend of loan words and new Englishes hence the landscape of the educational system in the country is visionary to produce holistic Filipino learners in the $21^{\text {st }}$ century. In the end, the product of every institution may market the skills of the learners and in the future the people will tell that once upon a time there was a one -stop -school in the Philippines.

\section{REFERENCES}

[1] Lyn, G. Asia Pacific Journal of Maritime Education University of Batangas, retrieved, January 10, 2018 Vol. 1 No. 2, 2015

[2] Bishop, G. Curriculum Development: A Textbook for Students: London Mcmillan. 1981.

[3] Akcan, S. and Tatar, s. The Perspectives of Teachers towards the in- class use of $5^{\text {th }}$ grade English Textbook. Retrieved from: http://oc.eab.org.tr.pdf/35.pdf., 20009.

[4] Ahmad Mazli Muhammad. (2007). The effectiveness of an academic reading course in facilitating tertiary students' comprehension of academic text. Unpublished Ph.D. thesis.Faculty of Education, UniversitiKebangsaanMaylia, Bangi.

[5] Ambigapathy, P. (2002). English language teaching in Malaysia today. Asia Pacific Journal of Education, 22(2), 35-52. (Online) Retrieved 30 January, 2011 from 
http://www.tandfonline.com/doi/abs/10.1080/02188790202 20205\#preview

[6] Ambigapathy, P. (2006). What works in the classroom? Promoting literacy practices in English. 3L. The Southeast Asian Journal of English Language Studies, 11, 15-39

[7] Baker, W. (2009). Language, culture and identity through English as a lingua franca in Asia: Notes from the field. Linguistics Journal (Special issue "Language, culture and identity in Asia"), 4, 8-35.

[8] GEMA OnlineTM Journal of Language Studies Volume 12(1), Special Section, January 2012

[9] Baynham, M., \&Prinsloo, M. (2009). Introduction: The future of literacy studies. In M. Baynham \& Prinsloo (Eds.), the future of literacy studies (pp.1-20). Great Britain: Palgrave Macmillan.

[10] Bowen, A. G. (2009). Document analysis as a qualitative research method. Qualitative Reasearch Journal, 9 (2), 27 40

[11] Fauziah Hassan \& Nita FauzeeSelamat. (2002). Why aren't students proficient in ESL: The teachers' perspective. The English, 18. (Online) Retrieved 9 December, 2010 from http://www.melta.org.my/ET/2002/wp10.htm

[12] Fereday, J. \& Muir-Cochrane, E. (2006).Demonstrating rigor using thematic analysis: A hybrid approach of inductive and deductive coding and theme development. International Journal of Qualitative Methods, 5(1), 80-92.

[13] HazitaAzman. (1999). Multilingual literacies in rural Malaysia: National goals and local practices. Unpublished $\mathrm{PhD}$. Thesis. Graduate School of Education, The University of Western Australia.

[14] HazitaAzman. (2009). English in Malaysia: A paradox in rural Pluri-literacy Practices. Akademika, 76, 27-41.

[15] Isarji Hj Sarudin, Ainol Madziah Zubairi, Mohamed Sahari Nordi \& Mohd Azmi Omar.(2008). The English language proficiency of Malaysian public university students. In Zuraidah Mohd Don, MdYusof Abu Bakar, Nor Aieni Haji Mokhtar, RohanaJani, Ainol Madaziah Zubairi, Norasma Othman \& Aries Gan (Eds.), Enhancing the quality of higher education through research: Shaping future policy (pp.40-65). The Ministry of Higher Education, Malaysia.

[16] Koo Yew Lie. (2008). Language, Culture and literacy: Meaning-making in global contexts. Bangi: Penerbit Universiti Kebangsaan Malaysia.

[17] Krishnakumari, K, Paul-Evanson, C., \&Selvanayagam, S. (2010) Preparing for change From MUET to academic writing. Paper read at MyCASELT 2010 The $3^{\text {rd }}$ Malaysia International Conference on Academic Strategies in English Language Teaching, at The Saujana Hotel, Kuala Lumpur, 15-16 December 2010.

[18] Lee king Siong, HazitaAzman\& Koo Yew Lie. (2010). Investigating the undergraduate experience of assessment in higher education. GEMA Online Journal of Language Studies, 10(1), 17-33.

[19] Lee Su Kim. (2003). Multiple identities in a multicultural world: A Malaysian perspective. Journal of Language, Identity and Education, 2(3), 137-158.
[20] Leki, I. (2007). Undergraduates in a second languge; Challenges and complexities in academic literacy development. New York: Lawrence Erlbaum Associates. 